\title{
Wildfire Impact on the Main Tree Species of the Near-Yenisei Siberia
}

\author{
A. V. Bryukhanov ${ }^{a, ~ *}$, A. V. Panov ${ }^{a}$, E. I. Ponomarev ${ }^{a, b}$, and N. V. Sidenko ${ }^{a}$ \\ ${ }^{a}$ Sukachev Institute of Forest, Siberian Branch, Russian Academy of Sciences, Krasnoyarsk, 660036 Russia \\ ${ }^{b}$ Siberian Federal University, Krasnoyarsk, 660041 Russia \\ *e-mail: bryukhanov1975@yandex.ru
}

\begin{abstract}
Wildfires are the major cause of forest death in Siberia, as well as one of the main ecological factors forming biodiversity. Here, we present the impact of surface wildfires on Northern Eurasian boreal ecosystems with the example of the main tree species in the Near-Yenisei Siberia. The wildfire impact in the study area is determined by the mean annual burning rate of $0.20 \pm 0.05 \%$. In the extremely dry summer of 2012 , this value increased to $19 \%$. The integral fire radiative power through the season reached $4.1 \times 10^{5} \mathrm{MW} / \mathrm{km}^{2}$, whereas the mean annual value did not exceed $0.64 \times 10^{5} \mathrm{MW} / \mathrm{km}^{2}$. Our observations demonstrate the highly variable effect of surface fires on conifer species in Siberia. Only trees with DBH $>5 \mathrm{~cm}$ survived a year after moderate severity surface fires. After high severity (usually steady) surface fires only pine trees with DBH $>$ $17.2 \mathrm{~cm}$ survived, while trees with $\mathrm{DBH}>18.1 \mathrm{~cm}$ were the most resistant within further post-fire succession.
\end{abstract}

Keywords: Siberia, surface fires, fire resistance, laser-based field instrumentation system, post-fire tree mortality, fire frequency, wildfire, remote sensing data, fire radiative power

DOI: $10.1134 /$ S0001433818110026

\section{INTRODUCTION}

Combustibility of forests and the level of fire impact are most important factors limiting sustainable functioning of Siberian ecosystems, where up to 70$90 \%$ of the annual number of forest fires in Russia are recorded (Shvidenko and Shchepashchenko, 2013; Ponomarev et al., 2016). According to experts (Bartalev et al., 2015), in the Siberian Federal Region every year after fires forest death occurs on territory from 1.5 to 3 million hectares. Up to $30 \%$ of registered fires lead to the change in the main canopy of forest stands (Krylov et al., 2014). A positive trend of mean temperatures during snowless period, uneven distribution of precipitation during the growing season, as well as the growth of forest anthropogenic disturbance determine the increase of combustibility in the region (de Groot et al., 2013; Kharuk et al., 2016).

Geospatial analysis of the distribution of fires (the scale of fire impact determined including the intensity of fires in modern conditions) can be carried out using remote sensing (Ponomarev and Kharuk, 2016; Ponomarev et al., 2017). At the same time, it is critical to have detailed ground-based survey data to calibrate and verify remote assessments. In this regard, we performed a series of ground-based experiments to assess post-fire state of stands in the Middle Taiga subzone of the Yenisei Siberia.

Significant number of works of domestic and foreign scientists is devoted to the study of fire resistance of plantings and fire resistance of the main forest- forming species in boreal (taiga) forests of Russia. Only in Siberia in the last two decades, a number of such studies have been conducted (Buryak, 1999; Furyaev et al., 2005; McRae et al., 2006; Tsvetkov, 2007; Ivanova et al., 2014, 2017; etc.). The key difference between our studies of the post-fire fallout of adult stands is the use of laser-based field instrumentation system for spatial mapping of trees forming the main canopy of the forest stand, undergrowth and underbrush clumps, as well as the location of the fallout. Application of this technique allowed us restoring the fire parameters in sampling plots, as well as to evaluate differentially the effect of species and intensity of combustion on woody plants.

\section{STUDY AREA AND METHODS}

Studies were conducted on the territory of the Middle Taiga subzone of Yenisei Siberia in the south of the Turukhanskoe Forestry in Krasnoyarsk krai in the forests largely affected by various forms of fires (Fig. 1). Sampling plots were located in the area adjacent to the ZOTTO Station (Heimann et al., 2017), the instrument cluster of which makes it possible to record the atmospheric signal at the origin of forest fires in the station area (Chi et al., 2013; Panov et al., 2015; Mikhailov et al., 2017) and affords the opportunity of linking the monitoring data of the atmospheric gas composition with ground-based measurements (Panov et al., 2016). The study area is characterized by high and extremely high combustibility. According to 
the World Resource Institute (Sizer et al., 2015), in the forest fund of the Russian Federation, central regions of Middle Siberia have the largest forest losses. Most of the reductions in the main canopy are due to fires.

Data on fires in the study area were summarized from instrumental satellite observations conducted at the V.N. Sukachev Institute of Forests of the SB RAS. The work used the technical capabilities of the receiving complexes of the Center for Collective Use and the Unified Regional Center for Remote Sensing of the FRS KSC of the SB RAS (Krasnoyarsk). Information on fires obtained during thematic processing of NOAA/AVHRR satellite surveys for the period 19962007 and Terra/MODIS for the period 2007-2016 and presented in the format of geographic information bank of fire polygons with attributive characteristics (date, coordinates, area, duration of fire, energy parameters of the active zone etc.) was used.

Standard methods used in forest pyrology for characterization of the fire-hazardous season were used. We used burning rate as the ratio of the total area of fires $\left(S_{\text {fire }}\right)$ per season to the total area of the test polygon $(S)$ :

$$
\gamma=\frac{\sum S_{\text {fire }}}{S} \times 100 \%
$$

In addition, we analyzed data in the middle infrared range (21 channels of TERRA/Modis radiometer with the operating range $\lambda=3.929-3.989 \mu \mathrm{m}$ ). The value of the signal recorded in this area of the electromagnetic spectrum is related to the power of heat released from the active zone of the fire. In a foreign publication (Justice et al., 2002), this characteristic is known as "fire radiative power" (FRP), or "heat radiative power". It is calculated by an empirical relation adapted from the Stefan-Boltzmann law:

$$
\mathrm{FRP}_{\mathrm{px}}=4.34 \times 10^{-19}\left(T_{\mathrm{tg}}^{8}-T_{\mathrm{bg}}^{8}\right) S_{\mathrm{px}},
$$

where $T_{\mathrm{tg}}$ and $T_{\mathrm{bg}}$ are the radio brightness temperature of the "fire" pixel (target) and the background, respectively, in the range $3.929-3.989 \mu \mathrm{m} ; S_{\mathrm{px}}$ is the pixel area, $\mathrm{m}^{2}$; the constant $4.34 \times 10^{-19} \mathrm{~W} /\left(\mathrm{m}^{2} \mathrm{~K}^{8}\right)$ was obtained experimentally (Kaufman et al., 1998).

The heat emission power associated with the amount of burning plant biomass can be used as a criterion for the intensity of combustion and the type of fire that characterizes the potential impact of fire on forest vegetation (Mota and Wooster, 2018).

Collecting data on the postfire state of all layers of the forest stand was carried out on stationary test areas, laid out mainly in conifer forests. Each sample area had at least 100 trees. Trial areas were laid mainly in pine plantations (Fig. 2). Deciduous and dark conifer stands are of less value for long-term research, as even weak ground fires lead to their almost complete death. Locations of sampling plots were determined in the course of preliminary work with remote sensing data (satellite images). Areas were selected with a uniform combustion power in low-level fires. The areas covered by the high-level fires were of less interest for the planned long-term studies; sampling plots were not laid in them due to the fact that the main canopy with this type of pyrogenic impact completely dies, as a rule, in the first year after combustion.

Selection, laying and description of sample plots were carried according to classical methods. To determine quantitative and qualitative characteristics of plantings and evaluation of large-scale wood residues on several sampling plots, we used the standard method of continuous enumeration using a high precision laser-based field instrumentation system in the state inventory of the forest fund (SIFF) by Roslesinforg (according to the order of the Federal Forestry Agency no 472, dated November 10, 2011, "On the approval of methodological recommendations for conducting state forest inventory"). The data included visual assessment of the life condition of woody plants higher than $1.3 \mathrm{~m}$ using a 10 -point scale and the presence of visible postfire damages, as well as indication of individual characteristics of each tree (curvature or slope of the trunk, lump volumes, presence of two tops etc.). In the future, for the ease of work, we used in the SIFF 10-point scale adapted to more common forestry technique (Alekseev, 1989). Diameters of trees were determined according to the standard procedure at the height of human breast $(1.3 \mathrm{~m})$. For recalculation, we have taken into account all woody plants that reached this height. Trees below $1.3 \mathrm{~m}$ were estimated as undergrowth, depending on their species.

In total, 832 trees were censused on five sampling plots. Among them, Pinus sylvestris L. prevailed: $46.6 \%$ of the stock. Among leaved trees, Betula pendula Roth composed 22.6\%; then Picea obovata Ledeb., 17.5\%; Pinus sibirica Du Tour, 7.3\%; Abies sibirica Ledeb., 2.0\%; Populus tremula L., 1.7\%; Larix sibirica Ledeb., $0.1 \%$; and undergrowth trees in small numbers: Salix rosmarinifolia L., Alnus sibirica (Spach) Turcz. ex Komar and Sorbus aucuparia L.

\section{RESULTS AND DISCUSSION \\ Combustibility of the Region}

During the period of satellite observations, extreme combustibility on the study area was observed in 1999, 2006, and 2012; the periodicity, therefore, was $7 \pm 2$ years. Mean annual values of combustibility of the study area were at the level $0.20 \pm 0.05 \%$. At the same time, in extreme fire-dangerous seasons the burning rate was significantly higher, up to $1.5 \%$; in 2012 , by two orders of magnitude higher, to $19 \%$ (Fig. 3). The proportion of forest fires with extreme heat emission in Siberia annually is $5.5 \pm 1.2 \%$ of the total number, which corresponds to the assessment $(8.5 \%)$ of the forest area of the Siberian territory annually exposed to high-intensity fires (Ponomarev et al., 

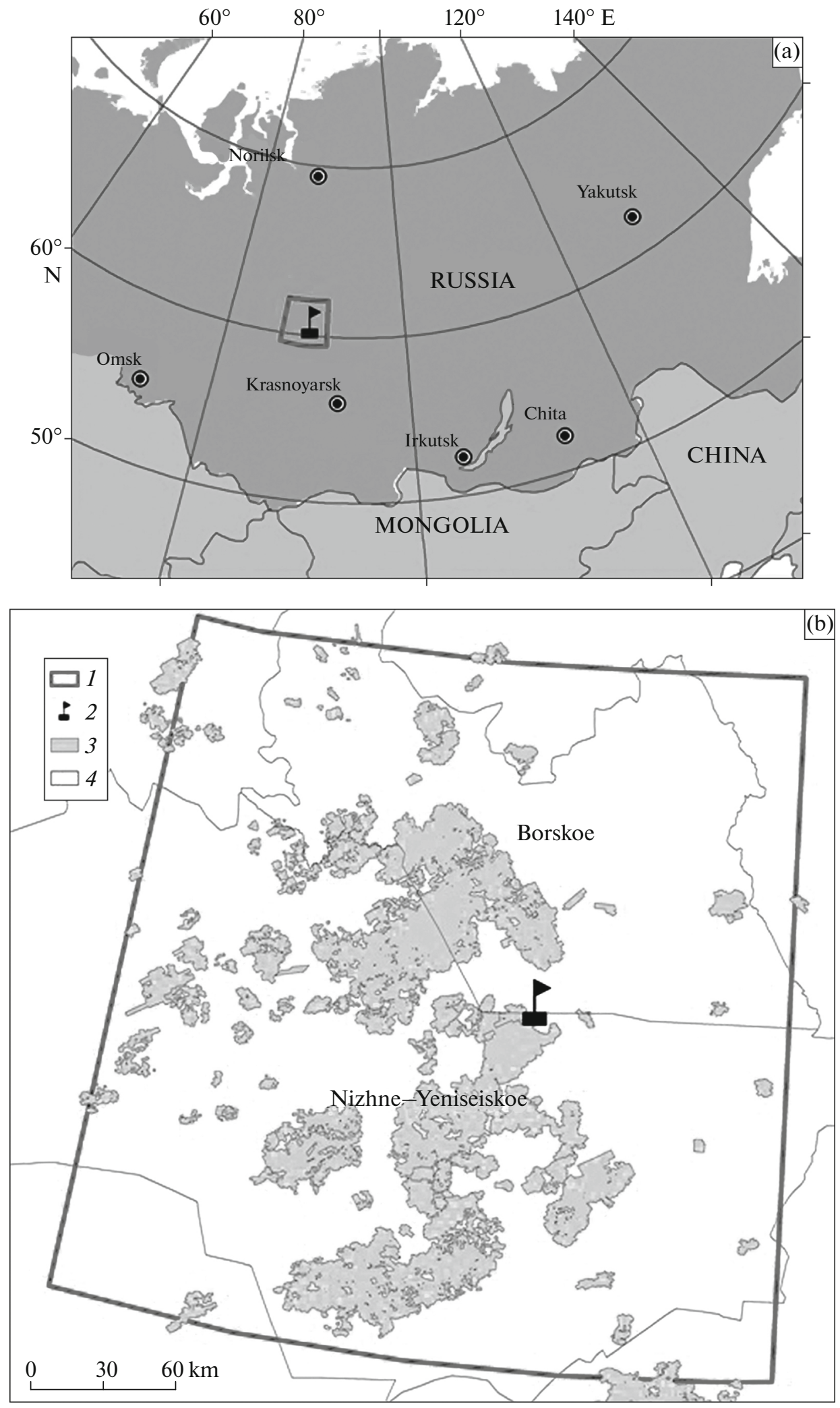

Fig. 1. (a) Position of the study area and (b) spatial distribution of fires by satellite monitoring data on 1996-2016. (b) 1-Margins of the territories studied; 2-location of the ZOTTO station (Mid-Yenisei Station of the V.N. Sukachev Institute of Forests, SB RAS); 3-burnt areas; 4-margins of forestry. 
Green moss

spruce forest
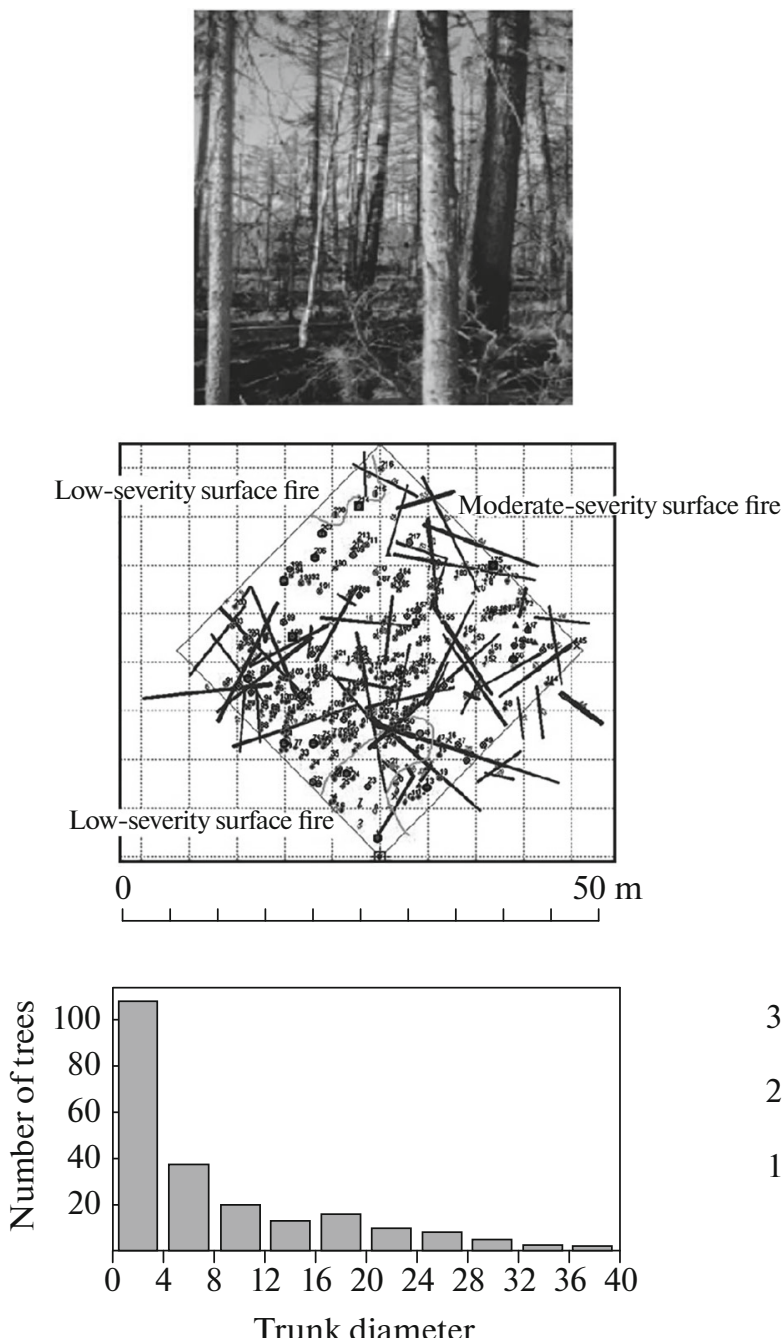

at the height of $1.3 \mathrm{~m}, \mathrm{~cm}$

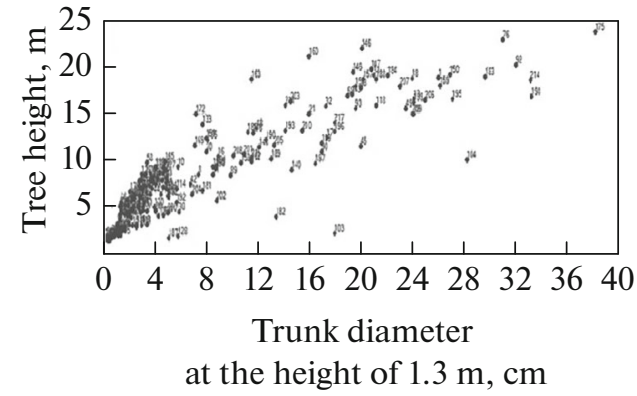

Forb birch

forest
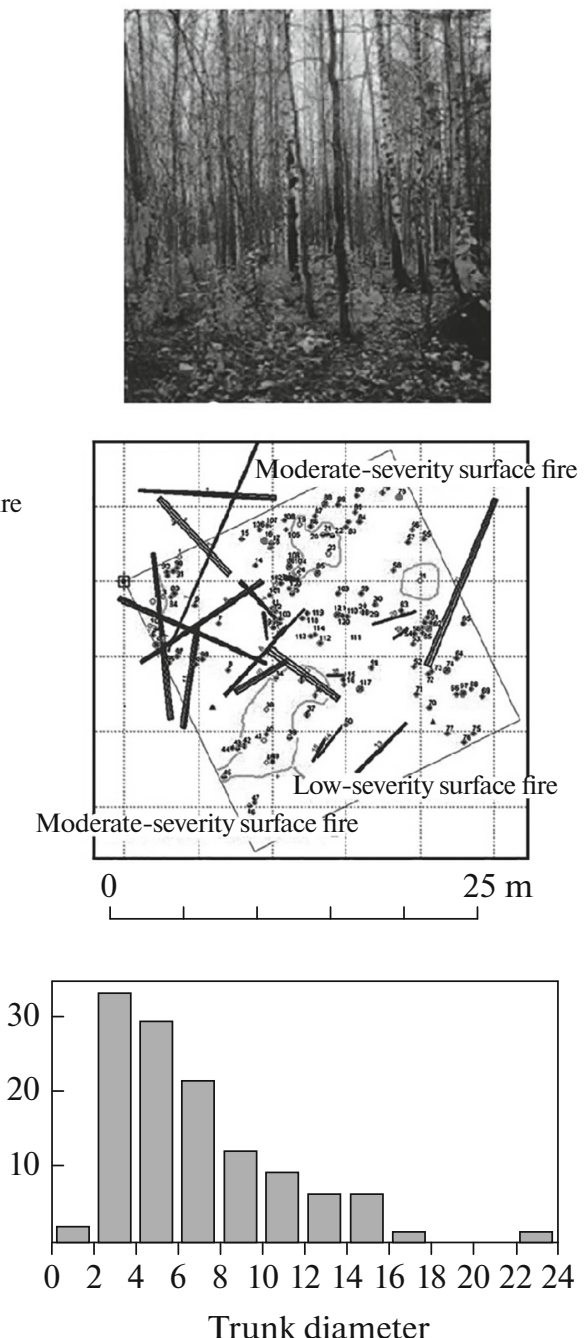

Trunk diameter at the height of $1.3 \mathrm{~m}, \mathrm{~cm}$

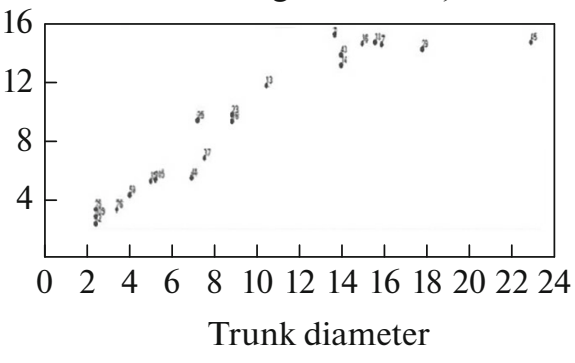

at the height of $1.3 \mathrm{~m}, \mathrm{~cm}$

Fig. 2. Forestry and pyrological characteristics of sampling plots. (a) On-site view; (b) spatial distribution of trees, stubs and fallout; (c) distribution of trees by the groups of trunk diameter at the height of $1.3 \mathrm{~m}$; (d) distribution of trees by heights depending on the diameter of the trunk at a height of $1.3 \mathrm{~m}$.

2017). The indicators of relative burned area are consistent with those for the whole of Siberia (de Groot et al., 2013; Ponomarev et al., 2016), including 2012 $(>19 \%)$, when this parameter fell within the range of possible extreme values of $15-25 \%$.
With the modern extent of fire influence on the forests of Siberia, the study of postfire condition and dynamics of tree stands require efficient methods of remote sensing of the intensity of burning. Just this factor largely determines the further direction of 

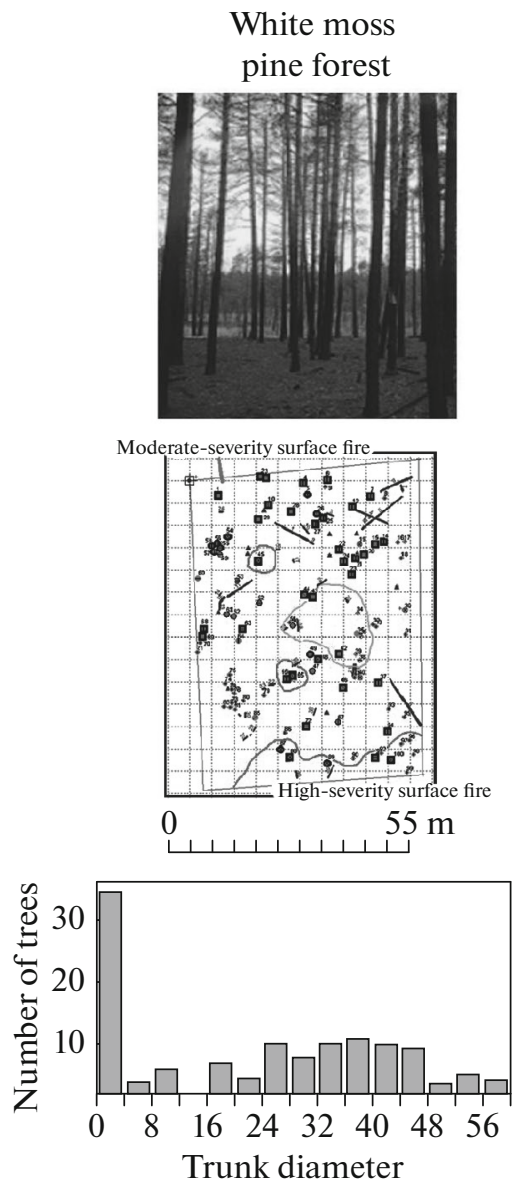

at the height of $1.3 \mathrm{~m}, \mathrm{~cm}$

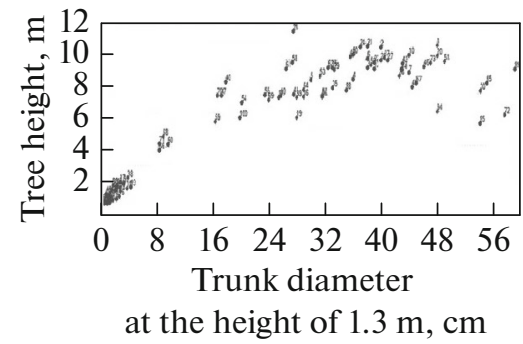

Sphagnum pine forest
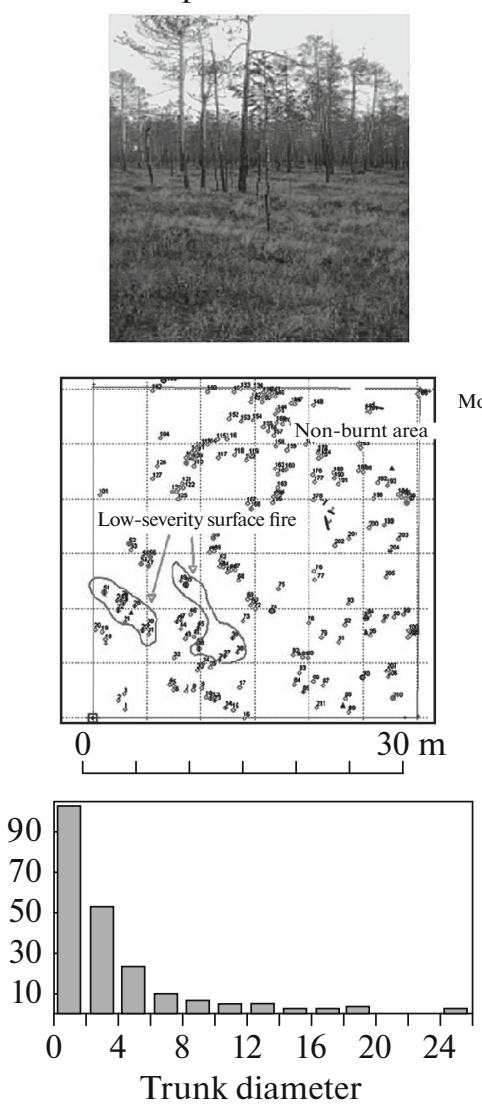

Trunk diameter at the height of $1.3 \mathrm{~m}, \mathrm{~cm}$

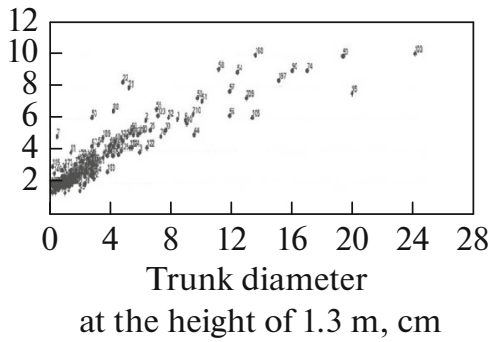

Green moss pine forest

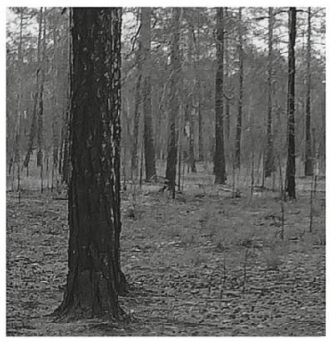

(a)
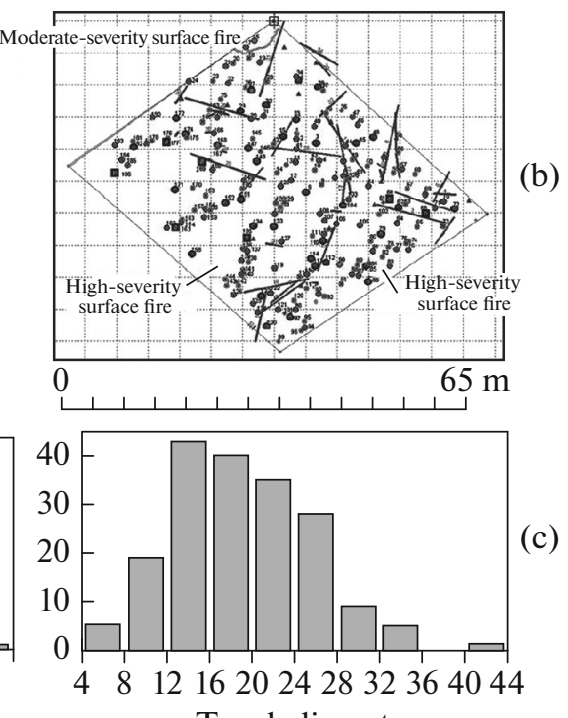

Trunk diameter

at the height of $1.3 \mathrm{~m}, \mathrm{~cm}$

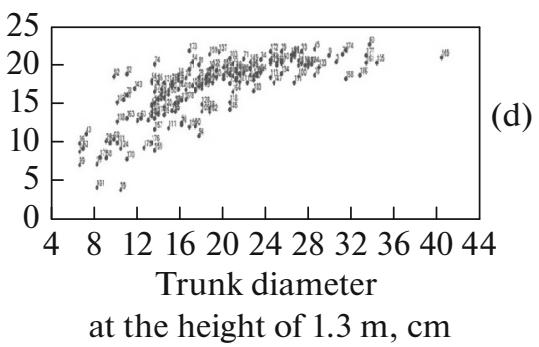

Fig. 2. (Contd.)

postfire successions (McRae et al., 2006; Krylov et al., 2014).

Due to the extreme nature of the 2012 fire season, most of sampling plots corresponded to the areas damaged by high-intensity fires. Variation in the values of the fire radiative power (FRP) from individual active combustion sites recorded by satellite also showed a fivefold excess of the maximum FRP (1694.3 MW/ $\mathrm{km}^{2}$ ) in 2012 over the mean multiyear level $\left(371.17 \mathrm{MW} / \mathrm{km}^{2}\right)$. The integral FRP from all wildfire per the season the season was $4.1 \times 10^{5} \mathrm{MW} / \mathrm{km}^{2}$ with mean annual value of $0.64 \times 10^{5} \mathrm{MW} / \mathrm{km}^{2}$. Extremely high rates of heat emission from fires can contribute to the implementa- tion of "scenarios" that lead to the fall of the main canopy of stands or change of forest-forming species.

\section{Postfire Fallout of Trees Depending on the Trunk Diameter and Species}

For the conditions of Middle Siberia, many researchers (Buryak, 1999; Furyaev et al., 2005; Valendik et al., 2006; Tsvetkov, 2007; Ivanova et al., 2014; etc.) noted a significant influence of the trunk diameter on the ability of trees to survive a fire. Our observations showed that this indicator should be considered only in combination with other factors. Thus, individual characteristics of the tree (attenuation by 
(a)

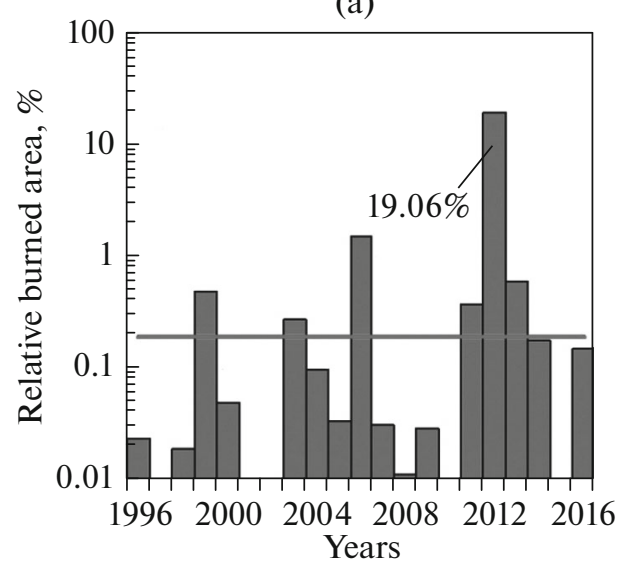

(b)

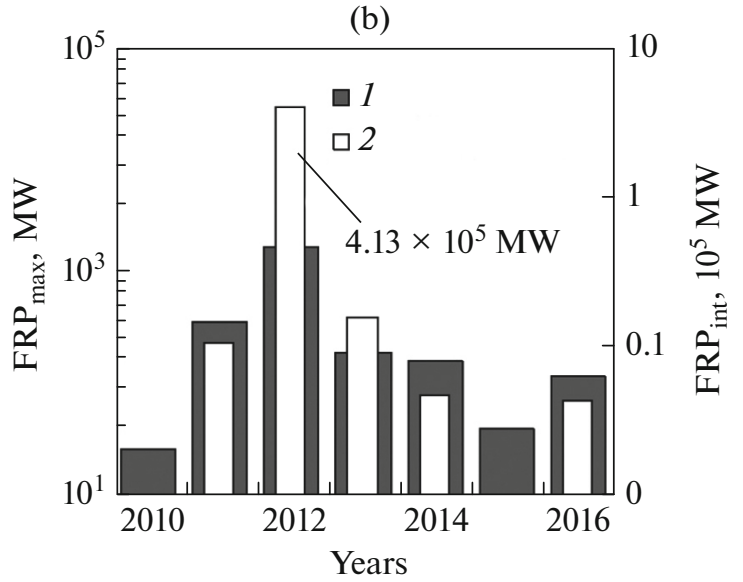

Fig. 3. Multiyear pyrological characteristics of the study area. (a) Burning rate by the data of satellite monitoring in $1996-2016$. Mean multiyear relative burned area, $0.20 \%$ is designated by line; (b) remote data on thermal radiative power (by FRP method) from fires of vegetation. (1) $\mathrm{FRP}_{\max }$; (2) FRP integral

various factors, morphometric characteristics of the trunk, damage etc.) and its location relative to the accumulation of combustible materials can contribute to both an increase of the combustion intensity and its reduction. The death of adult woody plants with a trunk diameter of more than $32 \mathrm{~cm}$, growing either close to the fallow or coniferous undergrowth, was noted, while standalone trees of much smaller diameter survived. Species composition is not less important. Pine trees with a trunk diameter of $16-24 \mathrm{~cm}$ were able to maintain viability after a low-level fire of medium intensity. At the same time, dark conifer species (siberian pine and spruce) with such an indicator died completely.

An important role in the proportion of tree fallout lies in their spatial position relative to each other, as well as relative to the fallen trees and undergrowth. As a result of the conjugate analysis of the spatial structure of the main canopy of stands on sampling plots, it was found that individual characteristics of trees (character of damage, presence of main conductors of combustion around the tree) and its location play an equally important role in the ability of woody plants to withstand highintensity low-level fire and not to die $(r=0.81)$ than the species $(r=0.74)$ and the diameter at the bottom of the trunk $(r=0.86)$ (Bryukhanov et al., 2014).

It was noted that the siberian fir has the least resistance to the pyrogenic effect among conifers. The death of $100 \%$ of the trees in the postfire year was recorded. The siberian spruce had a slightly better survival rate, and only trees with the trunk diameter less than $5 \mathrm{~cm}$ died in the first year after the thermal influence. In cases of low-level fires, the survival rate of siberian pine was worse than that of spruce. In the first year, only trees with the trunk diameter of $8 \mathrm{~cm}$ were able to survive. However, for trees with the diameter of $14 \mathrm{~cm}$ or more, there were cases when the cedar pine could remain viable after the moderate-severity fire.
On the plots with severe burning, in rare cases large cedar pines with trunk diameters from $28 \mathrm{~cm}$ survived; however, as shown by further observations, these trees also died in the second and third year after the fire (Fig. 4, Table 1).

The table on tree fallout does not include data on the study of fire resistance of the Siberian Larch due to the lack of a statistically significant number of trees on sampling plots. For leaved trees, the results for postfire fallout are presented, but not for all species. The number of aspen and woody plants, forming undergrowth (alder, willow and wild ash), was insignificant for the formation of a significant sample.

For birch, we recorded the ability to resist weak low-level fire in trees with trunk diameters from $2.3 \mathrm{~cm}$, and average low-level fire in trees with trunk diameters from $3 \mathrm{~cm}$. A year after severe low-level fire, only birches with trunk diameters from $14 \mathrm{~cm}$ are able to survive due to the undergrowth formed on the lower part of the trunk.

These data confirm that spruce, cedar pine and fir are of little use for long-term studies among all conifer species growing in Siberia, as the fallout of adult trees of these species in the first year after the fire reaches $50-100 \%$.

Based on our observations, it should be noted that the second year after fires is a demarcation, and in the third year, most of the surviving conifer trees show an improvement in the living condition (types of crowns assessed visually). All deciduous trees capable of forming the main canopy (birch and aspen) died, as a rule, in the first year after the fire, but the next season most of them showed stable vegetative recovery from roots or from trunk lumps. Aspen recovered especially rapidly; its growth reached $0.5 \mathrm{~m}$ per year. 
(a)

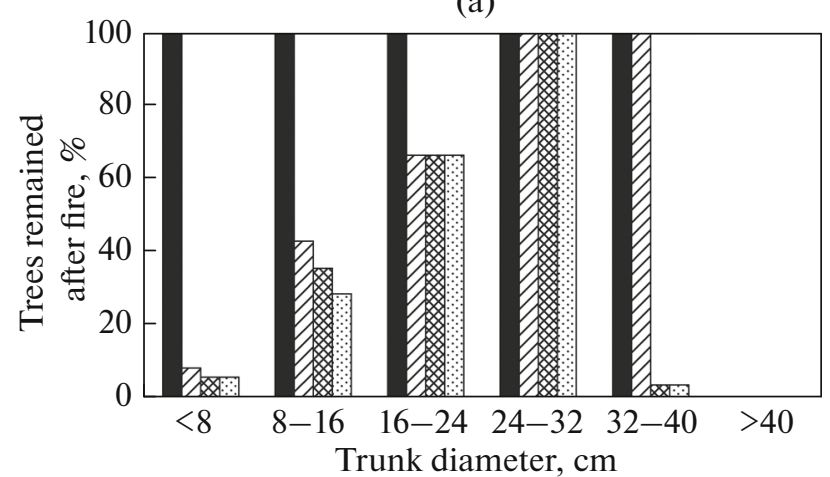

(b)

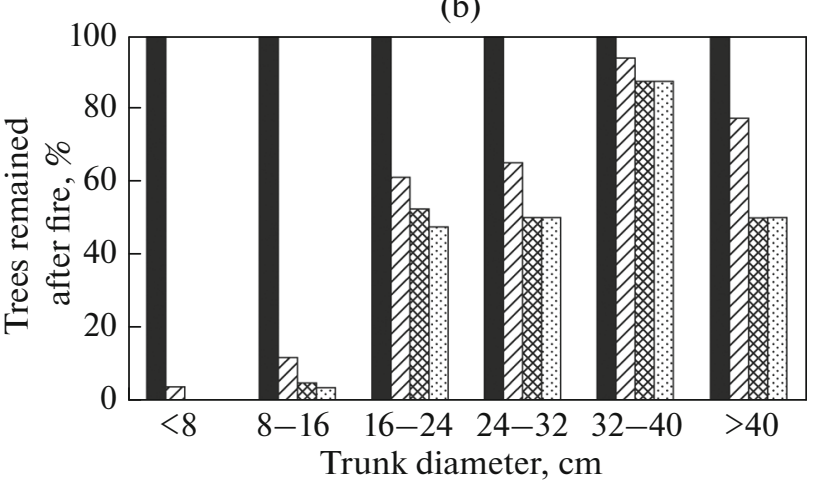

(c)

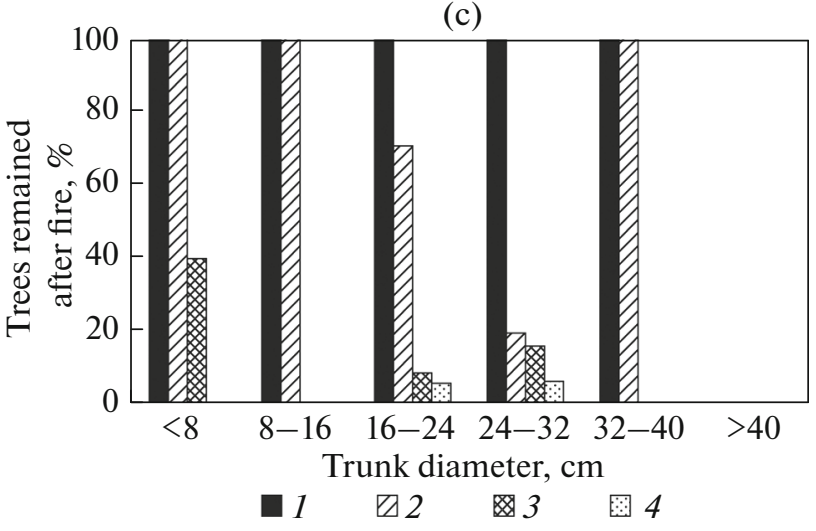

Fig. 4. Remaining pine trees by groups of trunk diameter depending on the power of fires on sampling plots: (a) weak, (b) average, (c) severe. (1-4) Number of pine trees on sampling plots: (1) before fire; (2) in the first year after fire; (3) on the second year after fire; (4) on the third year after fire.

\section{Influence of Morphometric Characteristics and Life Condition of Trees on Postfire Fallout}

Analysis of results revealed that the most significant factors affecting the postfire death of adult trees are surface location of the root system, trunk diameter and presence/absence of significant mechanical damage.

After weak low-level fires on the studied plots, single young pines with the trunk diameter from $0.5 \mathrm{~cm}$ and height of about $1.5 \mathrm{~m}$, forming undergrowth, were able to maintain viability, but only in those cases when the lower part of their crowns did not come into contact with dry grass, undershrub and shrubs, and there were no clusters of fallout and litter. In the case of average low-level fires, only trees with the trunk diameter from $5 \mathrm{~cm}$ could survive in a year. After strong low-level fires (as a rule, stable) in the first growing season, the viability was maintained exclusively by pines with the diameter from $17.2 \mathrm{~cm}$, and among trees with diameters of $18.1 \mathrm{~cm}$ and more; living specimens survived 2 and 3 years after thermal exposure.

Our observations are consistent with conclusions of a number of researchers (Furyaev et al., 2005; Tsvetkov, 2007; Ivanova et al. 2014, 2017; etc.) that the surface distribution of the root system leads to a strong decrease in fire resistance in all tree species, but most often such a morphological feature was observed in conifer species and much less frequently in deciduous ones. Large horizontal skeletal roots not covered with soil was the most important cause of the postfire fallout of trees, on average, $42 \%$ of running fires and $91 \%$ of the more robust ones. The most important factor for trees is damage to surface roots. Often, such damage forms a ribbed abundance of lumps with typical presence of "swarms" (recesses in the trunk), where a large number of combustion conductors are accumulated, which increases the intensity of fire when the flame approaches the tree. Further, the degree of influence on the weakening and fallout of trees after the fire is followed by such individual features of the structure of lower trunk parts as the slope and curvature. Mechanical damage to the trunk (before the fire) had a minimal impact on the survival of trees. The greatest fallout (on average, to $89 \%$ of stable low-level fires) was observed for pines having significant (more than $2 / 3$ of the circumference of the trunk) mechanical damage to the trunk (big old fire dry sites and carrs from tapping).

\section{CONCLUSION}

In the course of our study, it was found that average multiyear value of the burning rate in the forests of the Middle Taiga subzone of Yenisei Siberia in the south of Turukhanskoe Forest reached $0.20 \pm 0.05 \%$. The maximum value (19\%) was noted in the extreme fire season of 2012. Integral heat radiation from fires in the season of extreme burning reached $4.1 \times 10^{5} \mathrm{MW} / \mathrm{km}^{2}$ with the mean multiyear value of $0.64 \times 10^{5} \mathrm{MW} / \mathrm{km}^{2}$. The frequency of repetition of such scenarios in the region is $7 \pm 2$ years. With positive trends of relative burned area in the conditions of changing climate, the increase in the proportion of species-exchange fires should be expected.

In general, our studies demonstrated that in the conditions of Middle Siberia, weak low-level fires are resisted by conifer species extremely unevenly, and pyrogenic influence largely depends on species. Fir trees die almost completely; Siberian spruce and cedar 
Table 1. Tree fallout in the first year after fires by groups of trunk diameter for different species depending on the intensity of burning, $\%$

\begin{tabular}{|c|c|c|c|c|c|}
\hline \multirow{2}{*}{ Tree species } & \multicolumn{5}{|c|}{ Trunk diameter at the human breast height, $1.3 \mathrm{~m}$} \\
\hline & to $8 \mathrm{~cm}$ & $8-16 \mathrm{~cm}$ & $16-24 \mathrm{~cm}$ & $24-32 \mathrm{~cm}$ & $32-40 \mathrm{~cm}$ \\
\hline \multicolumn{6}{|c|}{ Low-severity surface fire } \\
\hline Pine & $\frac{90}{92.4}$ & $\frac{71.4}{73.1}$ & $\frac{25}{23.1}$ & 0 & 0 \\
\hline Birch & $\frac{6.7}{5.6}$ & 0 & Indet. & Indet. & - \\
\hline Spruce & $\frac{6.6}{7.1}$ & Indet. & Indet. & Indet. & Indet. \\
\hline Siberian pine & 100 & 100 & $\frac{66.6}{70.8}$ & Indet. & Indet. \\
\hline Fir & 100 & 100 & 100 & - & - \\
\hline \multicolumn{6}{|c|}{ Moderate-severity surface fire } \\
\hline Pine & $\frac{85.5}{99.6}$ & $\frac{82.1}{83.1}$ & $\frac{39.1}{35.3}$ & $\frac{28.6}{29}$ & 0 \\
\hline Birch & $\frac{78.9}{76}$ & $\frac{59.4}{54.5}$ & $\frac{87.5}{88.1}$ & Indet. & - \\
\hline Spruce & 100 & $\frac{80}{78.7}$ & Indet. & Indet. & Indet. \\
\hline Siberian pine & $\frac{80}{84.1}$ & $\frac{53.4}{51}$ & $\frac{42.9}{40.6}$ & $\frac{44.4}{43.4}$ & Indet. \\
\hline Fir & Indet. & Indet. & Indet. & - & - \\
\hline \multicolumn{6}{|c|}{ High-severity surface fire } \\
\hline Pine & 100 & 100 & $\frac{80}{78.4}$ & $\frac{77.4}{72.1}$ & Indet. \\
\hline
\end{tabular}

Numerator: by specimens; denominator: by storage; “-” trees of this diameter did not occur in samples; "indet." trees of a given group by diameters were not positioned on plots with indicated burning intensity in the number necessary for conduction of real statistical analysis.

pine are able to survive only weak low-level fires. Leaved species survive medium-sized fires solely due to their ability of vegetative recovery from "sleeping" buds on the roots and trunk. Individual peculiarities of trees and the diameter of the trunk lower part play a no less important role in the ability of trees to resist fire than their species.

\section{ACKNOWLEDGMENTS}

The work was supported by RFBR and the Government of Krasnoyarsk krai and Krasnoyarsk Regional Scientific Foundation, projects nos. 15-4504423_r_a and 17-41-240475_r_a.

\section{REFERENCES}

Alekseev, V.A., Diagnostics of the living state of trees and forest stands, Lesovedenie, 1989, no. 4, pp. 51-57.

Bartalev, S.A., Stytsenko, F.V., Egorov, V.A., and Lupyan, E.A., Satellite-based assessment of Russian forest fire mortality, Lesovedenie, 2015, no. 2, pp. 83-94.
Bryukhanov, A.V., Panov, A.V., Kalyakin, S.V., Sidenko, N.V., and Guzii, V.M., The use of methods of ground-based high-precision laser survey for assessing the post-fire consequences in fresh burnt areas and burnt timbers in Central Siberia, in Materialy Mezhdunar. konf. ENVIROMIS-2014 (Proceedings of the International Conference ENVIROMIS-2014), Tomsk: SCERT, 2014, pp. 197-200.

Buryak, L.V., The role of ground fires in the formation of light-coniferous plantings of southern Middle Siberia, Cand. Sci. (Agric.) Dissertation, Krasnoyarsk, 1999.

Chi, X., Winderlich, J., Mayer, J.-C., Panov, A.V., Heimann, M., Birmili, W., Heintzenberg, J., Cheng, Y., and Andreae, M.O., Long-term measurements of aerosol and carbon monoxide at the ZOTTO tall tower to characterize polluted and pristine air in the Siberian taiga, Atmos. Chem. Phys., 2013, no. 13, pp. 1227112298.

de Groot, W.J., Cantin, A.S., Flannigan, M.D., Soja, A.J., Gowman, L.M., and Newbery, A., A comparison of Canadian and Russian boreal forest fire regimes, For. Ecol. Manage, 2013, vol. 294, pp. 23-24. doi 10.1016/ j.foreco.2012.07.033 
Furyaev, V.V., Zablotskii, V.I., and Chernykh, V.A., Pozharoustoichivost' sosnovykh lesov (Fire Resistance of Pine Forests), Novosibirsk: Nauka, 2005.

Heimann, M., Lavric, J.V., Park, S., Kolle, O., Kuebler, K., Panov, A., Prokushkin, A., Timokhina, A., Skhorochod, A., Mikhailov, E., and Andreae, A., A 10-year climatology of greenhouse gas measurements and aerosols at the Zotino Tall Tower observatory (ZOTTO) in Central Siberia, Rep. Ser. Aerosol Sci., 2017, no. 201, pp. 165-167.

Ivanova, G.A., Konard, S.G., McRae, D.D., Bezkorovainaya, I.N., Bogorodskaya, A.V., Zhila, S.V., Ivanov, V.A., Ivanov, A.V., Kovaleva, N.M., Krasnoshchekova, E.N., Kukavskaya, E.A., Oreshkov, D.N., Perevoznikova, V.D., Samsonov, Yu.N., Sorokin, N.D., Tarasov, P.A., Tsvetkov, P.A., and Shishikin, A.S., Vozdeistvie pozharov na komponenty ekosistemy srednetaezhnykh sosnyakov Sibiri (Fire Impact on the Components of Siberian Middle Taiga Pinery), Novosibirsk: Nauka, 2014.

Ivanova, G.A., Ivanov, V.A., Kovaleva, N.M., Konard, S.G., Zhila, S.V., and Tarasov, P.A., Succession of vegetation after a high-intensity fire in lichen pine forest, Sib. Ekol. Zh., 2017, no. 1, pp. 61-71. http://www.sibran.ru/journals/issue.php?ID=169775\& ARTICLE_ID $=169782$.

Justice, C.O., Giglio, L., Korontzi, S., Owens, J., Morisette, J.T., Roy, D., Descloitres, J., Alleaume, S., Petitcolin, F., and Kaufman, Y., The MODIS fire products, Remote Sens. Environ., 2002, no. 83, pp. 244-262.

Kaufman, Y.J., Kleidman, R.G., and King, M.D., SCAR-B fires in the tropics: Properties and remote sensing from EOS-MODIS, J. Geophys. Res., 1998, vol. 103, no. D24, pp. 31955-31968.

Kharuk, V.I., Dvinskaya, M.L., Petrov, I.A., Im, S.T., and Ranson, K.J., Larch forests of Middle Siberia: Longterm trends in fire return intervals, Reg. Environ. Change, 2016, vol. 16, pp. 2389-2397. doi 10.1007/ s10113-016-0964-9

Krylov, A., McCarty, J.L., Potapov, P., Loboda, T., Tyukavina, A., Turubanova, S., and Hansen, M.C., Remote sensing estimates of stand-replacement fires in Russia, 2002-2011, Environ. Res. Lett., 2014, no. 9, 105007, pp. 1-8. doi 10.1088/1748-9326/9/10/105007

McRae, D.J., Conard, S.G., Ivanova, G.A., Sukhinin, A.I., Baker, S.P., Samsonov, Y.N., Blake, T.W., Ivanov, V.A., Ivanov, A.V., Churkina, T.V., Hao, W.M., Koutzenogij, K.P., and Kovaleva, N., Variability of fire behavior, fire effects and emissions in Scotch pine forests of Central Siberia, Mitigation Adapt. Strategies Global Change, 2006, vol. 11, no. 1, pp. 45-74. doi 10.1007/s11027-006-1008-4

Mikhailov, E., Mironova, S., Mironov, G., Vlasenko, S., Panov, A., Chi, X., Walter, D., Carbone, S., Artaxo, P., Poschl, U., and Andreae, M., Long-term measurements (2010-2014) of carbonaceous aerosol and carbon monoxide at the Zotino Tall Tower Observatory (ZOTTO) in Central Siberia, Atmos. Chem. Phys., 2017, no. 17 , pp. $14365-14392$. https://doi.org/10.5194/acp17-14365-2017

Mota, B. and Wooster, J.W., A new top-down approach for directly estimating biomass burning emissions and fuel consumption rates and totals from geostationary satellite fire radiative power (FRP), Remote Sens. Environ., 2018, vol. 206, pp. 45-62. https://doi.org/10.1016/ j.rse.2017.12.016

Panov A.V., Heintzenberg, J., Birmili, W., Seifert, P., Chi, S., Timokhina, A.V., and Andreae, M.O., Spatial distribution of atmospheric aerosols over the territory of Eurasia in middle and high latitudes, Geogr. Nat. Resour., 2015, vol. 36, no. 1, pp. 25-30.

Panov, A., Prokushkin, A., Korets, M., Bryukhanov, A., Myers-Pigg, A., Louchouarn, P., Sidenko, N.V., Amon, R., Andreae, M.O., and Heimann, M., Linking trace gas measurements and molecular tracers of organic matter in aerosols for identification of ecosystem sources and types of wildfires in Central Siberia, IOP Conf. Ser.: Earth Environ. Sci., 2016, vol. 48, 012017. http://iopscience.iop.org/article/10.1088/17551315/48/1/012017. doi 10.1088/1755-1315/48/1/ 01201710.1088/1755-1315/48/1/012017

Ponomarev, E.I. and Kharuk, V.I., Wildfire occurrence in forests of the Altai-Sayan region under current climate changes, Contemp. Probl. Ecol., 2016, vol. 9, no. 1, pp. 29-36. doi 10.1134/S199542551601011X

Ponomarev, E.I., Kharuk, V.I., and Ranson, K.J., Wildfires dynamics in Siberian larch forests, Forests, 2016, no. 7, pp. 1-9. doi 10.3390/f7060125

Ponomarev, E.I., Shvetsov, E.G., and Usataya, Yu.O., Records of energy characteristics of wildfires in Siberian forests using remote methods, Issled. Zemli Kosmosa, 2017, no. 4, pp. 3-11. doi 10.7868/ S0205961417040017

Rosleskhoz Order no. 472 of November 10, 2011, On Approval of Methodological Recommendations for the State Forest Inventory (with changes of May 7, 2013). http://docs.cntd.ru/document/902325555.

Shvidenko, A.Z. and Schepaschenko, D.G., Climate change and wildfires in Russia, Contemp. Probl. Ecol., 2013, vol. 6, no. 5, pp. 50-61.

Sizer, N., Petersen, R., Anderson, J., Hansen, M., Potapov, P., and Thau, D., Tree cover loss spikes in Russia and Canada remains high globally, 2015. http:// www.wri.org/blog/2015/04/tree-coverloss-spikes-russiaand-canada-remains-high-globally.

Tsvetkov, P.A., Ustoichivost' listvennitsy Gmelina k pozharam $v$ severnoi taige Srednei Sibiri (Fire Resistance of Larix gmelinii in Northern Taiga of Middle Siberia), Krasnoyarsk: SibGTU, IL SO RAN, 2007.

Valendik, E.N., Sukhinin, A.I., and Kosov, I.V., Vliyanie nizovykh pozharov na ustoichivost' khvoinykh porod (Influence of Ground Fires on the Stability of Coniferous Species), Krasnoyarsk: SO RAN, 2006.

Translated by S. Kuzmin 